Vol. (3)(01), (Juli-Desember)(2021), (Halaman)(38-47)

DOI: https://doi.org/10.24127/j-sanak.v3i01.1510

\title{
STRATEGI PEMBELAJARAN PADA ANAK USIA DINI DI MASA PENDEMI COVID-19
}

\author{
Leni Indriani ${ }^{1}$ \\ IAIN Padangsidimpuan \\ leniindriani27@gmail.com \\ Dina Khairiah ${ }^{2}$ \\ IAIN Padangsidimpuan \\ addinakhairiah@iain-padangsidimpuan.ac.id \\ Ali Wardhana Manalu ${ }^{3}$ \\ Sekolah Tinggi Ilmu Tarbiyah Hamzah Al- Fansuri Sibolga-Barus \\ awardhana774@gmail.com
}

\begin{abstract}
ABSTRAK
Pandemi Covid-19 yang terjadi di 2 tahun terakhir membawa dampak yang cukup serius. Bukan hanya ekonomi, kesehatan dan juga keamanan yang terdampak namun dunia pendidikan juga terkena dampaknya secara langsung. Pengaruh Covid-19 mempengaruhi proses belajar mengajar langsung (tatap muka) di dunia pendidikan memberikan pengaruh besar terhadap mental anak khususnya pada anak usia dini. Proses belajar pada anak usia dini di masa pandemi Covid-19 akan berjalan dengan baik apabila menerapkan strategi pembelajaran yang tepat. Metode yang digunakan dalam penelitian ini adalah metode kualilatif deskriptif. Strategi pembelajaran sangat dibutuhkan agar proses belajar mengajar pada anak usia dini dapat tercapai dengan optimal sehingga tujuan yang diharapkan sesuai dengan yang direncanakan. Secara umum dapat menerapkan strategi inkuiri dan kontekstual dalam proses pembelajaran pada era Covid-19.
\end{abstract}

Kata Kunci: Strategi Pembelajaran, Pandemi Covid-19

Received 27-11-2021; Received in revised form 30-12-2021 ; Accepted 31-12-2021

\begin{abstract}
The Covid-19 pandemic that has occurred in the last 2 years has had a fairly serious impact. Not only the economy, health and security are affected, but the world of education is also directly affected. The influence of Covid-19 affecting the direct (face-to-face) teaching and learning process in the world of education has a major impact on children's mentality, especially in early childhood. The learning process for early childhood during the Covid-19 pandemic will run well if you apply the right learning strategies. The method used in this research is descriptive qualitative method. Learning strategies are needed so that the teaching and learning process in early childhood can be achieved optimally so that the expected goals are as planned. In general, you can apply inquiry and contextual strategies in the learning process in the Covid-19 era.
\end{abstract}

Keyword: Learning Strategy, Covid-19 Pandemic 


\section{A. PENDAHULUAN}

Pendidikan merupakan hal yang sangat penting bagi setiap individu. Karena dengan pendidikan manusia dapat berubah menjadi yang lebih baik lagi. Pendidikan dapat mencetak sumber daya manusia yang terampil, berkarakter dan cerdas. Demikian pula di Indonesia sangat menekankan kepada pendidikan. Namun, sejak terjadinya wabah virus Covid-19 yang mendunia, pendidikan di dunia menjadi terganggu khususnya pendidikan di Indonesia yang menjadikan pembelajaran yang awalnya tatap muka berubah menjadi pembelajaran di rumah.

Dengan terjadinya perubahan pembelajaran tersebut guru sebagai tenaga pendidik yang cermat menyiasati hal tersebut agar pembelajaran tetap terlaksana sebagaimana yang diharapkan. Rencana dan tahapan yang cermat untuk mencapai sasaran khusus dalam mendidik anak disebut strategi (Rahmah, 2016).

\section{B. PEMBAHASAN}

Istilah strategi (strategy) berasal dari "kata benda" dan "kata kerja" dalam bahasa Yunani. Sebagai kata benda, strategos merupakan gabungan dari kata Stratos (militer) dengan ago (memimpin). Sebagai kata kerja, stratego berarti merencanakan (to Plan actions). Hardy, Langlay, dan Rose dalam Sudjana, mengemukakan: "Strategy is perceived as plan ora set of explicit intention preceeding and controlling actions (strategi dipahami sebagai rencana atau kehendak yang mendahului dan mengendalikan kegiatan) (Majid, 2013).

Strategi secara umum mempunyai pengertian suatu garis-garis besar haluan untuk bertindak dalam usaha mencapai sasaran yang telah ditentukan (Bahri D, 1996). Istilah strategi mula-mula dipakai di kalangan militer dan diartikan sebagai seni dalam merancang peperangan,terutama yang erat kaitannya dengan gerakan pasukan dan navigasi ke dalam posisi perang untuk memperoleh kemenangan. Seiring dengan berjalannya waktu, istilah strategi banyak digunakan dalam bidang pengajaran, termasuk dalam strategi mendidik anak usia dini. Dihubungkan dengan mendidik anak usia dini, strategi bisa diartikan sebagai pola-pola umum kegiatan orang tua dalam pendidikan anak usia dini untuk mencapai tujuan pendidikan yang diharapkan.

Sifat strategi itu masih perencanaan tentang keputusan yang akan diambil untuk menentukan sasaran yang diinginkan. Pada konteks pembelajaran, strategi merupakan suatu perencanaan pendidik dalam berinteraksi terhadap anak agar proses pembelajaran sesuai dengan yang diharapkan. Hal ini sesuai dengan Riyanto (2010:132) yang berpendapat bahwa strategi pembelajaran adalah siasat guru dalam mengefektifkan, mengefesienkan, serta mengoptimalkan fungsi dan interaksi siswa dengan komponen pembelajaran dalam suatu kegiatan pembelajaran untuk mencapai tujuan pengajaran. 
Majid (2011:15) mengatakan bahwa perencanaan adalah menyusun langkahlangkah yang akan dilaksanakan untuk mencapai tujuan yang telah ditentukan.Maka dalam konteks pembelajaran, perencanaan diartikan sebagai proses penyusunan materi pelajaran, penggunaan media pembelajaran, penggunaan metode pengajaran dalam suatu alokasi waktu yang sudah ditentukan.

Berkenaan dengan itu, Sanjaya (2011) engatakan tentang karakteristik perencanaan pembelajaran ada 3yaitu:

1. Perencanaan pembelajaran merupakan hasil proses berpikir, artinya suatu perencanaan pembelajaran disusun tidak asal-asalan akan tetapi disusun dengan mempertimbangkan segala aspek yang mungkin dapat berpengaruh, di samping disusun dengan mempertimbangkan segala sumber yang tersedia yang dapat mendukung terhadap keberhasilan proses pembelajaran,

2. Perencanan pembelajaran disusun untuk mengubah perilaku siswa sesuai dengan tujuan yang ingin dicapai,

3. Perencanaan pembelajaran berisi tentang rangkaian kegiatan yang harus dilaksanakan untuk mencapai tujuan.

Berdasarkan dari uraian pendapat diatas bahwa perencanaan adalah pemikiran dari seorang pendidik sebelum memulai kegiatan pembelajaran terhadap anak.

Pendidikan pertama pada anak tumbuh dari lingkungan keluarga, sehingga anak pertama kali mendapatkan bimbingan serta pendidikan bukan dari lingkungan sekolah melainkan dari lingkungan keluarga. Keluarga memiliki tugas utama untuk pendidikan anak, yaitu sebagai acuan dasar mengenai pendidikan keagamaan, nilai budaya, serta nilai moral sebagai modal dalam bersosialisasi dalam lingkungan masyarakat (Supriyono et al., 2015).

Kegiatan pendidikan yang dilaksanakan dalam keluarga, tidak bisa dilepaskan dari pendidikan sebelumnya yakni dalam kandungan atau sebelum lahir, sekitar saat kelahiran, saat baru lahir dan setelah kelahiran, termasuk pendidikan usia dini. Dengan demikian bila dikaitkan dengan pendidikan, maka pendidikan anak usia dini merupakan serangkaian yang masih ada keterkaitannya untuk mewujudkan generasi unggul dan pendidikan itu memang merupakan sebuah kebutuhan dalam kehidupan manusia. Kewajiban orang tua adalah merawat dan memelihara anaknya sebagai generasi penerus dalam keluarga, karena banyak realita dalam masyarakat, manusia dan remaja yang jahat, nakal, sadis, membunuh, memperkosa, merampok, penjudi dan mabuk-mabukan, masalahnya mungkin saja doa dan niat orang tuanya belum jelas mengenai keturunan yang harapkan, bahkan mungkin orang tidak punya niat apa-apa mengenai keturunannya (Fadli, 2020).

Pendidikan dapat ditinjau dari dua segi, yakni dari pandangan masyarakat dan segi pandangan individu. Pandangan masyarakat berarti pewarisan budaya dari generasi tua kepada generasi muda agar hidup masyarakat itu tetap 
berkelanjutan. Jadi, masyarakat mempunyai nilai-nilai budaya yang ingin disalurkan dari generasi ke generasi agar identitas masyarakat tersebut terpelihara. Di lihat dari segi individu pendidikan berarti pengembangan potensi-potensi yang terpendam dan tersembunyi. Dengan kata lain, kemakmuran manusia tergantung pada keberhasilan pendidikan dalam mencari dan menggarap kekayaan yang terpendam dalam setiap individu (Langgulung, 1995).

Pentingnya masa anak dan karakteristik anak usia dini, menuntut pendekatan yang kan digunakan dalam kegiatan pembelajaran yang memusatkan perhatinaanya pada anak. Lebih lanjut pusat kurikulum balitbang depdiknas mendifinisiakan pembelajaran anak usia dini sebagai berikut:

Pertama, proses pembelajaran bagi anak usia dini adalah proses interaksi antaranak, sumber belajar dan pendidikan dalam suatu lingkungan belajar tertentu untuk mencapai tujuan yang telah ditetapkan. Kedua, sesuai dengan karakteristik anak usia dini yang bersifat aktif melakukan berbagai eksplorasi dalam kegiatan bermain, maka proses pembelajarannya ditekankan pada aktivitas anak dalam bentuk belajar sambil bermain. Ketiga, belajar sambil bermain di tekankan pada pengembangan potensi dibidang fisik (koordinasi motorik halus dan kasar), kecerdasan (daya pikir, daya cipta, kecerdasan emosi dan kecerdasan spiritual), sosio emosional (sikap prilaku serta agama), bahasa dan komunikasi menjadi komptensi atau kemampuan yang secara aktual dimiliki anak. Keempat, penyelenggaraan pembelajaran bagi anak usia dini perlu diberikan rasa aman bagi anak usia tersebut. Kelima, sesuai dengan sifat perkembangan anak usia dini proses pembelajarannya dilaksanakan secara terpadu. Keenam, proses pembelajaran akan terjadi apabila anak secara aktif beriteraksi dengan lingkungan belajar yang diatur pendidikan. Ketujuh, program belajar mengajar dirancang dan dilaksanakan sebagai suatu system yang dapat menciptakan kondisi yang mengungah dan memberi kemudahan bagi anak usia untuk belajar sambil bermain melalui berbagai aktvitas yang bersifat konkret, dan yang sesuai dengan tingkat pertumbuhan dan perkembangan serta kehidupan anak usia dini. Kedelapan, keberhasilan proses pembelajaran ditandai dengan pencapaian pertumbuhan dan perkembangan anak usia secara optimal dan mampu manjadi jembatan bagi anak usia dini untuk menyesuaikan diri dengan lingkungan dan perkembangan selanjutnya (Sujud, 1995).

Dengan tujuan pendidikan anak usia dini untuk mengembangkan seluruh potensi anak agar kelak dapat berfungsi sebagai manusia yang utuh sesuai falsafah suatu bangsa, manusia utuh dalam pandangan islam disebut insan kammil atau manusia sempurna,untuk menjadi manusia sempurna atau utuh harus terpelihara fitrah dalam dirinya (Alauwiyah, 2018). Rendahnya pengetahuan dan pemahaman keluarga dalam kedudukan keluarga dan tanggung jawab mengenai pendidikan anak di rumah. Kurangnya pengetahuan dan pemahaman orang tua disebabkan oleh 
kurangnya inisiatif orang tua untuk belajar guna mendukung pendidikan anak dalam keluarga. Tanpa orang tua sadari sesungguhnya keluarga memiliki peran penting dalam perkembangan dan pendidikan anak. Perlu ditingkatkan pengetahuan orang tua mengenai cara mendidik anak agar berjalan optimal. Era digital mempermudah orang tua untuk mencari informasi yang valid dan berasal dari sumber-sumber yang terpercaya. Keperdulian orang tua merupakan faktor penentu keberhasilan anak dalam belajar, tidak lain merupakan faktor eksternal (Rahmah, 2016).

Adapun secara umum strategi pembelajaran dapat dilihat sebagai berikut:

1. Strategi Pembelajaran Exspositori; Strategi pembelajaran expositori adalah strategi pembelajaran yang menekankan kepada proses penyampaian materi secara verbal dari seseorang pendidik kepada sekelompok peserta didik dengan maksud agar peserta didik dapat menguasai materi pelajaran secara optimal.

2. Strategi Pembelajaran Inkuiri; Strategi pembelajaran inkuiri menekankan kepada proses mencari dan menemukan. Materi pelajaran tidak diberikan secara langsung. Peran peserta didik dalam strategi ini adalah mencari dan menemukan sendiri materi pelajaran, sedangkan pendidik berperan sebagai fasilitator dan pembimbing peserta didik untuk belajar (Sanjaya, 2011).

3. Strategi Pembelajaran Kontekstual; Strategi pembelajaran konstektual merupakan suatu proses pendidikan yang holistic dan bertujuan memotivasi peserta didik untuk memahami makna materi pelajaran yang dipelajarinya dengan mengaitkan materi tersebut dengan konteks kehidupan mereka seharihari (konteks pribadi, sosial, dan kultural) sehingga peserta didik memiliki pengetahuan/keterampilan yang secara fleksibel dapat diterapkan (ditransfer) dari satu permasalahan/konteks ke permasalahan/konteks lainnya. Pendekatan kontekstual (Contextual Teacing and Learning) merupakan konsep belajar yang membantu pendidik mengaitkan antara materi yang diajarkan dengan situasi dunia nyata peserta didik dan mendorong peserta didik membuat hubungan antara pengetahuan yang dimilikinya dengan penerapannya dalam kehidupan mereka sebagai anggota keluarga dan masyarakat (Kependidikan, 2008).

Saat ini, di masa pandemi Covid-19 pembelajaran dengan bimbingan orang tua diharapkan maksimal sebagai bentuk kolaborasi antara orang tua dan pendidik yang berperan sebagai pendidik di dua lingkungan yang berbeda. Kolaborasi yang dilakukan diharapkan dapat memberikan hal baru yang dapat dijadikan sebagai motivasi belajar anak usia dini di masa pandemi covid-19. Motivasi belajar anak di usia dini tidak lepas dari peran orang tua dan pendidik 
dalam menerapkan strategi pembelajaran yang dapat meningkatkan dan mengembalikan gairah belajar peserta didik di lingkungan keluarga dan sekolah.

Pada masa pandemi, orang tua banyak memiliki waktu bersama anak-anaknya sehingga anak cenderung berkembang melalui pengasuhan yang diberikan orang tua. Setiap orang tua memiliki cara yang berbeda dalam memperlakukan anaknya dan setiap pola asuh memiliki kekurangan serta kelebihan. Orang tua sesuai dengan pola asuhnya dituntut untuk menciptakan kondisi yang berkualitas sehingga orang tua mampu memberikan stimulus dengan baik. Tujuannya adalah supaya potensi dalam diri anak dapat berkembang maksimal. Apabila pola asuh orang tua dan stimulus yang diberikan tidak sesuai maka berpotensi akan salah arah. Pendidik dan orang tua berperan dalam proses pembelajaran di masa pandemi covid-19 oleh karena itu, perlu menerapkan strategi pembelajaran yang tepat agar dapat menunjang peserta didik sejak dini.

Dalam penelitian sederhana ini mencakup tentang bagaimana starategi pembelajaran anak usia dini di masa pendemi covid-19. Tujuan mini penelitian dengan memaparkan stategi pembelajaran antara pendidik dan orang tua berperan dalam proses pembelajaran di masa pandemi covid-19 oleh karena itu, perlu menerapkan strategi pembelajaran yang tepat agar dapat menunjang peserta didik sejak dini.

Peraturan pemerintah no. 19 tahun 2005 Bab IV pasal 19 dikatakan bahwa proses pembelajaran diselenggarakan secara interaktif, inspiratif, menyenangkan, menantang, dan memotivasi anak didik untuk berpartisipasi aktif, berprakarasa, kreatif dan mandiri sesuai dengan bakat minat dan perkembangan fisik serta psikologis anak didik.

Pertama Interaktif, Interaktif mengandung makna bahwa mengajar bukan hanya sekedar menyampaikan pengetahuan dari guru ke anak didik, melainkan mengajar sebagai proses mengatur lingkungan yang dapat merangsang anak untuk belajar. Dengan demikian melalui proses interaksi memungkinkan anak berkembang baik mental maupun intelektual.

Kedua Inspiratif, Inspiratif mengandung makna agar setiap anak didik selalu mencoba dan melakukan hal-hal yang baru dengan mendapatkan informasi dan dapat memecahkan masalahnya sendiri. Dengan demikian guru harus memberikan kesempatan kepada setiap anak didik agar dapat berbuat dan berpikir sesuai dengan inspirasinya.

Ketiga Menyenangkan, Menyenangkan mengandung makna bahwa pembelajaran untuk anak didik terbebas dari rasa takut dan menegangkan. Oleh karena itu guru harus mengupayakan situasi pembelajaran yang menyenangkan, dimulai dengan penataan lingkungan main yang bagus dan menarik, serta memenuhi unsur kesehatan, mulai dari kebersihan lingkungan main, pengaturan cahaya apabila belajar di dalam ruangan, ventilasi yang baik, dan memenuhi 
unsur keindahan. Misalnya cat dinding yang segar dan bersih, lukisan dan karyakarya anak yang tertata rapi, media dan sumber belajar yang relevan, dan bahasa tubuh guru yang mampu membangkitkan motivasi belajar anak didik.

Keempat Menantang, Menantang mengandung makna bahwa pembelajaran adalah proses yang menantang anak didik untuk mengembangkan kemampuan berpikir untuk merangsang kerja otak secara maksimal. Kemampuan menantang dapat melalui aktifitas kerja anak dengan mencoba berbagai kegiatan main memanfaatkan bahan main yang berasal dari daun-daunan, tanah liat, lumpur, dan lain-lain sehingga secara tidak langsung anak sudah berpikir secara intuitif atau bereksplorasi. Apabila guru hendak memberikan informasi, harus mampu membangkitkan anak didik menelan untuk memikirkan sebelum mengambil kesimpulan. Kelima Motivasi, Motivasi mengandung makna dorongan dari dalam jiwa anak didik untuk bertindak atau melakukan sesuatu. Dorongan itu hanya mungkin muncul dalam diri anak didik manakala anak didik merasa membutuhkan. Dengan demikian anak didik belajar tidak sekedar memperoleh nilai atau pujian melainkan didorong oleh rasa ingin tahu sesuai kebutuhannya.

\section{METODOLOGI}

Metode yang digunakan dalam penelitian ini adalah metode kualilatif deskriptif. Alasan menggunakan metode penelitian kualitatif adalah sebuah fenomena yang kompleks dapat diakomodasi dengan menggunakan metode yang terbuka dan penggunaan teori hanya berfungsi mengembangkan sensitivitas peneliti untuk memandu jalannya penelitian dan mengungkapkan permasalahan yang diteliti.

Populasi adalah wilayah generalisasi yang terdiri atas objek atau subjek yang mempunyai kualitas dan karakteristik tertentu yang ditetapkan oleh peneliti untuk dipelajari dan kemudian ditarik kesimpulannya (Kuncoro, 2013). Populasi dalam penelitian ini adalah pendidik dan orang tua yang dekat dengan lokasi peneliti. Sampel dalam penelitian ini adalah 4 orang saja yang memiliki anak yang bersekolah di Pendidikan Anak Usia Dini Anakki Do Hamoraoan Bandar Tarutung.

Teknik pengumpulan data penelitian ini adalah wawancara semi struktur. Teknik pencatatan wawancara semi struktur dengan menggunakan voice recorder handphone dan wawancara tidak struktur dengan menggunakan catatan kecil. Peneliti juga mencari sumber literatur yang bisa dijadikan pembahasan dalam penelitian strategi pembelajaran anak usia dini.

Teknik Analisis Data dalam penelitian ini adalah teknik analisis data kualitatif yang dilakukan sesuai dengan pendekatan fenomenologi, sehingga analisis data yang digunakan dengan cara mengeksplorasi pengalaman-pengalaman subjektif dan mengklarifikasi situasi yang dialami dalam kehidupan sehari-hari. Dari 
pertanyaan wawancara kemudian di analisis setiap jawaban responden dan mengidentifikasikannya sesuai dengan maksud dan tujuan penelitian.

\section{HASIL DAN PEMBAHASAN}

Responden penelitian menyadari pembelajaran yang baik dan tepusat pada anak perlu dilakukan sejak dini, ada beberapa jenis strategi pembelajaran untuk anak usia dini di masa pandemi Covid -19, antara lain:

1. Strategi pembelajaran langsung, Yaitu materi pembelajaran disajikan langsung pada anak didik dan anak didik langsung mengolahnya, misalnya bermain balok, puzzle, melukis dan lain-lain. Diharapkan anak didik bekerja secara menyeluruh dan peran guru hanya sebagai fasilitator.

2. Strategi belajar individual, Dilakukan oleh anak didik secara mandiri. Kecepatan, kelambatan dan keberhasilan pembelajaran anak didik sangat ditentukan oleh masing-masing individu anak yang bersangkutan.

3. Strategi belajar kelompok, Secara beregu. Bentuk belajar kelompok bisa dalam pembelajaran kelompok besar, dan kelompok kecil. Strategi kelompok tidak memperhatikan kecepatan belajar individual karena setiap individu dianggap sama. Oleh karena itu belajar kelompok dapat terjadi pada anak didik yang memiliki kemampuan tinggi akan terhambat oleh anak didik yang kemampuannya biasa-biasa saja. Strategi pembelajaran kelompok dapat dikatakan strategi pembelajaran deduktif dan induktif.

4. Strategi pembelajaran deduktif Adalah strategi pembelajaran yang dilakukan dengan mempelajari konsep-konsep, kemudian dicari kesimpulan dan ilustrasi dari yang abstrak menuju ke hal yang kongkret. Strategi ini disebut juga strategi pembelajaran dari umum ke khusus.

5. Strategi induktif, Bahan yang dipelajari dimulai dari hal-hal yang konkret kemudian secara perlahan anak didik dihadapkan pada materi yang cukup rumit, strategi ini dinamakan strategi pembelajaran dari khusus ke umum.

Pandemi Covid-19 ini mengharuskan anak belajar di rumah, pendidik harus mampu mengkondisikan setiap strategi yang digunakan. Disamping menerapkan strategi secara umum dan khusus pendidik perlu mengelola strategi pembelajaran bermain di luar sekolah. Pengelolaan bermain anak dapat dibedakan menjadi dua yakni di dalam sekolah dan di luar sekolah atau di dalam kelas dan di luar kelas. Pendemi covid-19 mengharuskan anak usia dini harus bermain di luar kelas atau di luar sekolah.

Adapun pengelolaan kegiatan main anak dengan kegiatan di luar kelas meliputi lingkungan di luar kelas yang dapat digunakan untuk tempat belajar.Taman, telaga, danau, kebun dan yang lainnya, merupakan tempat yang menarik untuk anak-anak belajar dan bertumbuh. Namun perlu menjadi perhatian khusus orang tua bahwa pembelajaran di luar kelas atau di luar sekolah di 
masa pandemic memiliki dampak negatif. Dampak negatif yang dapat ditimbulkan yakni rasa khawatir dari diri anak mempengaruhi mental anak itu sendiri.

Keunggulannya adalah anak-anak dapat menunjukan ketertarikan secara alami dan rasa ingin tahu yang dalam. Disini anak-anak dapat belajar disemua tempat perkembangan dan guru guru dapat meningkatkan pertumbuhan mereka melalui pengamatan, interaksi dan kegiatan yang telah direncanakan. Lingkungan diluar kelas menambah keseimbangan hari. Sangat sehat dan baik untuk anak-anak dan guru dalam menghirup udara segar, merasakan udara, menikmati kebebasan ruangan terbuka dan menggunakan otot-otot dengan cara yang baru.

Beberapa dampak positf dari kegiatan di luar kelas adalah sebagai berikut :

Pertama, Perkembangan Fisik Diluar ruangan, anak-anak akan semakin tahu bagaimana tubuh mereka bekerja dalam ruangan yang berbeda dengan merasakan kekuatan fisik, keseimbangan, dan stamina dikembangkan dengan terampil.

Kedua, Keterampilan Sosial Budaya Lingkungan diluar secara alami mendorong interaksi diantara anak dan lingkungannya. Suara keras diluar ruangan sangat diperbolehkan dan menyanyi dan berteriak juga akan menjadi media interaksi mereka. Beberapa anak yang pendiam akan lebih mudah bergaul ketika berada di luar ruangan. Karena keadaan di luar yang dinamis pula, guru-guru akan mampu mengamati anak-anak lebih jauh.

Ketiga, Perkembangan Intelektual Perkembangan intelektual akan meningkat bagi setiap anak ketika belajar di luar ruang kelas. Mereka akan dapat melihat proses alami secara langsung dan mendokumentasikannya dalam setiap kegiatan yang berlangsung. Hal ini tentu jauh lebih baik daripada anak-anak dipaksa untuk membayangkan beberapa peristiwa alam yang hanya diungkapkan secara verbal oleh guru. Lingkungan diluar akan membuat anak-anak mengembangan imajinasi daya khayalnya serta mengasah kreativitas mereka.

\section{E. KESIMPULAN}

Strategi pembelajaran sangat dibutuhkan agar proses belajar mengajar pada anak usia dini dapat tercapai dengan optimal sehingga tujuan yang diharapkan sesuai dengan yang direncanakan. Pendidik sebagai orang terdekat dengan kehidupan anak di luar lingkungan keluarga memberikan pengaruh yang sangat besar terhadap pertumbuhan dan perkembangan kecerdasan anak. Strategi pembelajaran yang diterapkan oleh pendidik selama pandemi covid-19 akan bernilai baik apabila diterapkan dengan maksimal didukung dengan peran orang tua serta mengindahkan prinsip-prinsip pembelajaran pada anak usia dini. 
Pendidik sebagai sumber belajar di luar lingkungan, keluarga menjadi hal sentral dalam proses pembelajaran. Proses pembelajaran akan berjalan dengan baik apabila menerapkan strategi dan prinsip pembelajaran dengan baik. Strategi pembelajaran pada era covid-19. Secara umum dapat menerapkan strategi inkuiri dan kontekstual. Secara khusus strategi pembelajaran yang dapat diterapkan yakni strategi belajar individual, peserta didik dapat mengontrol diri dalam kegiatan belajar. Kecepatan, kelambatan, dan keberhasilan pembelajaran anak didik sangat ditentukan oleh masing-masing individu yang bersangkutan selama pandemi covid-19.

\section{F. DAFTAR PUSTAKA}

Alauwiyah, M. D. (2018). Strategi Pendidikan Pendidikan Anak Usia Dini Di Panti Asuhan Amanah Kota Arga Makmur KAB. Bengkulu Utara. Institut Agama Islam Negeri Bengkulu.

Bahri D, S. (1996). Stategi Belajar Mengajar. Rineka Cipta.

D. T. (2008). Strategi Pembelajaran dan Pemilihannya. Jakarta: Direktorat Tenaga Kependidikan Direktorat Jenderal Peningkatan Mutu Pendidik Dan Tenaga Kependidikan, 35.

Kuncoro, M. (2013). Metode Riset Untuk Bisnis dan Ekonomi. Erlangga.

Langgulung, H. (1995). Beberapa Pemikiran tentang Pendidikan Islam. Al Maa'rif. Majid, A. (2013). Strategi Pembelajaran. PT. Remaja Rosda Karya.

Rahmah, S. (2016). Peran Keluarga Dalam Pendidikan Akhlak. Alhiwar Jurnal Ilmu Dan Teknik Dakwah, 04(07), 13-23. http://biblioteca.ibge.gov.br/visualizacao/monografias/GEBIS-

RJ/RBG/RBG1995v57_n1.pdf\%0Ahttps://periodicos.ufpe.br/revistas/rbgfe/ article/view/234295

Sanjaya, W. (2011). Strategi, Pembelajaran Berorientasi Standar Proses Pendidikan. Kencana Prenadamedia Group.

Sujud, A. (1995). DAP dan Paradigma Baru Pendidikan Anak Usia Dini (PAUD). IKIP.

Supriyono, Iskandar, H., \& Sucahyono. (2015). Pendidikan Keluarga Dalam Perspektif Masa Kin. 1-113. http://repositori.kemdikbud.go.id/6172/

Fadli, H. (2020). Strategi Pembelajaran Anak Usia Dini Di Masa Pendemi Covid19. Jurnal Mahasantri, 1(2), 1-26. 